\title{
Effect of Bovine Plasma Protein on Autolysis and Gelation of Protein Extracted from Giant Squid (Dosidicus gigas) Mantle
}

\author{
Laura Raquel Marquez-Alvarez, ${ }^{1}$ Wilfrido Torres-Arreola,, ${ }^{1}$ Victor Manuel Ocano-Higuera, ${ }^{2}$ \\ Benjamin Ramirez-Wong, ${ }^{1}$ and Enrique Marquez-Rios ${ }^{1}$
}

\author{
${ }^{1}$ Departamento de Investigación y Posgrado en Alimentos, Universidad de Sonora, Boulevard Luis Encinas y Rosales $s / n$, \\ 83000 Hermosillo, SON, Mexico \\ ${ }^{2}$ Departamento de Ciencias Químico Biológicas, Universidad de Sonora, Boulevard Luis Encinas y Rosales $s / n$, \\ 83000 Hermosillo, SON, Mexico
}

Correspondence should be addressed to Enrique Enrique; emarquez@guayacan.uson.mx

Received 1 June 2015; Accepted 13 August 2015

Academic Editor: Maria B. P. P. Oliveira

Copyright (C) 2015 Laura Raquel Marquez-Alvarez et al. This is an open access article distributed under the Creative Commons Attribution License, which permits unrestricted use, distribution, and reproduction in any medium, provided the original work is properly cited.

\begin{abstract}
The effect of bovine plasma protein (BPP) on the inhibition of autolytic activity and its effect on the gelling properties of a protein concentrate (PC) obtained from jumbo squid (Dosidicus gigas) mantle were investigated. Sols and gels were prepared from the PC by adding different amounts of BPP $(0,1$, and $2 \%)$. Dynamic oscillatory measurements indicated that systems with $1 \%$ BPP had a higher elastic modulus $\left(G^{\prime}\right)$, in which hydrophobic interactions were favored. Concerning the technological and textural quality of the gels, BPP caused a greater water holding capacity (WHC), force, cohesiveness, and elasticity, probably due to improvement of the electrostatic and hydrophobic interactions during gel formation. Scanning electron microscopy (SEM) allowed visualization of the formation of more rigid and ordered gels with less porosity when BPP was added. Therefore, the addition of BPP improved the gelling capacity of proteins extracted from giant squid.
\end{abstract}

\section{Introduction}

The giant squid (Dosidicus gigas) is the largest and most abundant species of squid found in the pelagic zone of the eastern Pacific from Chile to the coast of Oregon. Among the main species of squid caught in Mexico, it is the only fishery with a significant development in the north Pacific [1]. The commercial appeal of the giant squid is its abundance, low cost, high performance, low fat, and white color of the meat [2]. These features are exploited mainly by the seafood industries that trade in this species, manufacturing products such as gel type emulsified products. However, published studies about gelation from cephalopod muscle outline major challenges related to the specific characteristics of the myofibrillar proteins and high autolytic activity, and it has been suggested that tissue from the giant squid is not suitable for the preparation of a gel-like product. One disadvantage is the presence of endogenous proteases, of which the most active are calpains and cathepsins, which cause problems with gelation such as textural changes, protein aggregation, and decreased water holding capacity and gel strength $[3,4]$.

Certain proteins are widely used to improve gel strength by inhibiting autolysis caused by endogenous proteases [5] An example of this type of protein is bovine plasma protein, which has been recognized as the most effective protease inhibitor and a better agent for reinforcing surimi gels [6]. Benjakul and Visessanguan [7] found that porcine plasma protein effectively inhibited proteolytic activity in Pacific hake muscle (Pacific hake) and the autolytic activity of surimi. Consequently, this research used different concentrations of bovine plasma protein to study the effect on the autolytic activity and gelling properties of myofibrillar proteins extracted from giant squid mantle (Dosidicus gigas), in order to establish improved processing conditions and promote the economic recovery of the species. 


\section{Materials and Methods}

2.1. Samples. Giant squid (Dosidicus gigas) were captured on the coast of Baja California Sur in June 2014. Specimens were eviscerated and placed in a cooler, using alternating ice-squid-ice layers, and were transported to the Seafood Laboratory of the University of Sonora. The squid mantles were skinned, washed, and frozen at $-20^{\circ} \mathrm{C}$ until use.

2.2. Bovine Plasma Protein (BPP). Bovine blood was obtained from the Pecson slaughterhouse located in Hermosillo, Sonora, Mexico, in March 2014. To prevent clotting, $100 \mathrm{~mL}$ of a $3.8 \%(\mathrm{w} / \mathrm{v})$ sodium citrate solution was added per liter of blood during collection. To remove the red cells, the blood was subsequently centrifuged twice at $1500 \times \mathrm{g}$ for $30 \mathrm{~min}$ at $4^{\circ} \mathrm{C}$ in a refrigerated centrifuge. The supernatant (blood plasma) was lyophilized and kept at $-78^{\circ} \mathrm{C}$ until use. The plasma protein content was determined using the microKjeldahl method [8].

2.3. Preparation of Sols and Gels. Giant squid mantle was partially thawed at $4^{\circ} \mathrm{C}$ for $12 \mathrm{~h}$. The mantle was minced and homogenized with cold distilled water $\left(4-6^{\circ} \mathrm{C}\right)$ in a $1: 3$ ratio (muscle: water). The resulting suspension was centrifuged at $13000 \times \mathrm{g}$ for $15 \mathrm{~min}$ at $4^{\circ} \mathrm{C}$. The protein concentrate obtained was mixed with lyophilized plasma protein at concentrations of $0 \%$ (control), $1 \%$, and $2 \%$. Immediately after developing the sol, the moisture of the mixture was adjusted to $80 \%$, and $2.5 \%$ salt was added. The mixture was homogenized for $3 \mathrm{~min}$ at $4^{\circ} \mathrm{C}$. The resulting sol was placed in a glass Petri dish (with a height of $1 \mathrm{~cm}$ ) and packed in bags. The sols were later incubated and warmed to $90^{\circ} \mathrm{C}$ for $30 \mathrm{~min}$ in a water bath. Immediately after heating, the gels were cooled in an ice bath at 0 to $2^{\circ} \mathrm{C}$ for $30 \mathrm{~min}$ and stored at $4^{\circ} \mathrm{C}$ overnight before the functional and structural analysis was performed.

\subsection{Effect of Bovine Plasma Protein (BPP) on Autolytic Activity}

2.4.1. Autolysis Assay. Autolytic activity was studied to determine the conditions for maximum autolytic activity on the protein extract according to the method described by Morrissey et al. [9]. Three grams of sols (without BPP) was incubated in a water bath at temperatures of $20,30,35,40,45$, $50,55,60,65,70$, or $80^{\circ} \mathrm{C}$, for 10,30 , or $60 \mathrm{~min}$. Then, $27 \mathrm{~mL}$ of cold 5\% trichloroacetic acid (TCA) was added. The mixtures were homogenized on ice for $1 \mathrm{~h}$, and the homogenates were centrifuged at $5000 \mathrm{~g}$ for $5 \mathrm{~min}$ to remove the undissolved residue. The concentration of TCA-soluble peptides in the supernatant was determined using the method of Lowry et al. [10] and is expressed as micromoles of tyrosine per gram of sample.

2.4.2. Assay of BPP Inhibitory Activity. The inhibitory activity of bovine plasma protein (BPP) for autolysis was determined according to the method of Morrissey et al. [9] with slight modifications. The activity was measured in sols containing $1 \%$ to $2 \%$ BPP. Three grams of sol with BPP was incubated in a water bath at $35^{\circ} \mathrm{C}$ for $60 \mathrm{~min}$; these conditions were previously determined to be the best for autolysis. Then, $27 \mathrm{~mL}$ of $5 \%$ cold trichloroacetic acid (TCA) was added. The mixtures were then homogenized on ice for $1 \mathrm{~h}$, and the homogenates were centrifuged at $5000 \mathrm{~g}$ for $5 \mathrm{~min}$ to remove undissolved residue. The concentration of TCA-soluble peptides from the supernatant was determined using the method of Lowry et al. [10] and is expressed as micromoles $(\mu \mathrm{m})$ of tyrosine per gram of sample. The inhibitory effect of bovine plasma protein is expressed as percent inhibition using the following formula:

$$
\% \text { Inhibition }=\frac{(A-B) \times 100}{A},
$$

where $A$ is the tyrosine content in the sample without added protein and $B$ is the tyrosine content in the sample with BPP added.

\subsection{Molecular Characterization}

2.5.1. Determination of Total Sulfhydryl (SHT). Proteins from sols and gels were dissolved in Tris- $\mathrm{HCl}$ buffer to obtain a concentration of $0.6 \%$ protein. A $5 \mathrm{~mL}$ aliquot was taken from this solution and combined with $1 \mathrm{~mL}$ of $2 \mathrm{mM} 5,5^{\prime}$-dithiobis2-nitrobenzoic acid (DTNB) (prepared in phosphate buffer at $\mathrm{pH} 7.0$ ); then, $1.44 \mathrm{~g}$ of urea was added, and the color was allowed to develop for $40 \mathrm{~min}$. The volume was adjusted to $7 \mathrm{~mL}$ with Tris- $\mathrm{HCl}$ buffer, and the solution remained at room temperature until analysis. The absorbance of the supernatant was measured at $412 \mathrm{~nm}$. The SHT concentration in solution was calculated using a molar extinction coefficient of $13,600 / \mathrm{M} / \mathrm{cm}[11]$.

2.5.2. Surface Hydrophobicity $\left(S_{0} A N S\right)$. The interaction between the ANS reagent and hydrophobic regions of proteins can cause fluorescence emission when irradiated with appropriate electromagnetic radiation. Therefore the fluorescence intensity is proportional to protein concentration. For this essay, proteins from sols were dissolved in Tris$\mathrm{HCl}$ buffer to a concentration of $1.2 \%$ protein. Solutions were serially diluted to obtain protein concentrations of 0.02 , $0.03,0.04,0.05$, and $0.06 \%$. Immediately thereafter, $20 \mu \mathrm{L}$ of 15 mM 1-anilino-8-naphthalenesulfonate (ANS) was added. Subsequently, $3 \mathrm{~mL}$ of the sample was excited at $325 \mathrm{~nm}$, and the fluorescence intensity was measured at an emission wavelength of $420 \mathrm{~nm}$. The surface hydrophobicity $\left(\mathrm{S}_{0}\right)$ was determined by the slope of the graph of fluorescence intensity versus protein concentration, according Kato and Nakai [12].

2.5.3. Electrophoretic Profile (SDS-PAGE). The electrophoretic profile of each protein system was analyzed by polyacrylamide gel electrophoresis (PAGE) using a dissociating sodium dodecyl sulfate (SDS) buffer system in a discontinuous gel (4\% stacking gel and 10\% separating gel) according to the method of Laemmli [13]. A Mini PROTEAN 3 Cell Multicasting Chamber (Bio-Rad Laboratories, Hercules, CA) was used. Electrophoretic runs were performed at room temperature $\left(25^{\circ} \mathrm{C}\right)$ at $80 \mathrm{~V}$. Thirty $\mu \mathrm{g}$ of protein was loaded into each gel lane, and a broad-range molecular weight protein standard solution (Bio-Rad Laboratories, Richmond, CA) 
containing myosin $(200 \mathrm{kDa})$, beta-galactosidase $(116 \mathrm{kDa})$, phosphorylase $\mathrm{b}(97 \mathrm{kDa})$, bovine serum albumin $(66 \mathrm{kDa})$, ovalbumin $(45 \mathrm{kDa})$, and carbonic anhydrase $(31 \mathrm{kDa})$ was used as a standard. After electrophoresis, the gel was stained with $0.125 \%(\mathrm{w} / \mathrm{v})$ Coomassie brilliant blue R-250 in $40 \%$ $(\mathrm{v} / \mathrm{v})$ methanol and $7 \%(\mathrm{v} / \mathrm{v})$ acetic acid and then destained in $50 \%(\mathrm{v} / \mathrm{v})$ methanol and $10 \%(\mathrm{v} / \mathrm{v})$ acetic acid.

\subsection{Macrostructural Characterization}

2.6.1. Water Holding Capacity (WHC). The WHC was measured using the technique of Jiang et al. [14]. A $5 \mathrm{~g}$ sample (gel) was centrifuged at $3000 \times \mathrm{g}$ for $20 \mathrm{~min}$ at $4^{\circ} \mathrm{C}$. The WHC is expressed as the percentage of water retained in relation to the total amount of water present in the sample prior to centrifugation.

2.6.2. Texture Profile Analysis (TPA). The texture profile was evaluated on a texture analyzer TA-TX2 Plus. A compression cell, $3.8 \mathrm{~cm}$ in diameter, was used at a speed of $1 \mathrm{~mm} / \mathrm{s}$, using two cycles of compression to $75 \%$. The gels were cut into cylindrical portions $(1 \mathrm{~cm} \times 1 \mathrm{~cm})$ and remained at room temperature for 30-40 min prior to analysis.

2.6.3. Viscoelasticity. Viscoelasticity was determined on sols using a rheometer (Rheometric Scientific, Model RSF III, Piscataway, NJ, USA) according to the procedure described by Campo-Deaño et al. [15]. The sample was placed in a parallel flat dish of $25 \mathrm{~mm}$ and separated by $2 \mathrm{~mm}$. The storage modulus $\left(G^{\prime}\right)$ was continuously monitored at a fixed frequency of $3 \mathrm{~Hz}$ as a function of temperature, which was increased from 5 to $95^{\circ} \mathrm{C}$ at a heating rate of $5^{\circ} \mathrm{C} / \mathrm{min}$.

\subsection{Microstructural Characterization}

2.7.1. Differential Scanning Calorimetry (DSC). Forty mg of sol was placed in a calorimeter cell, ensuring good contact between the sample and the lower face of the capsule. The samples were scanned at a heating rate of $5^{\circ} \mathrm{C} / \mathrm{min}$ within a range of $4-100^{\circ} \mathrm{C}$, at a sensitivity of $0.5 \mathrm{mV} / \mathrm{cm}$. The denaturation temperature $\left(T_{d}\right)$ and denaturation enthalpy $(\Delta H)$ were monitored [16].

2.7.2. Scanning Electron Microscopy (SEM). The gel microstructure was observed by scanning electron microscopy (SEM). Gels, $3 \mathrm{~mm}$ thick, were fixed with glutaraldehyde $(2.5 \% \mathrm{v} / \mathrm{v})$ in phosphate buffer $(0.2 \mathrm{~mol} / \mathrm{L}$, pH 7.2). Subsequently, samples were rinsed for $1 \mathrm{~h}$ in distilled water before drying in an ethanol series of 50, 70, 80, 90, and 100\% (v/v). Dried samples were mounted on a bronze strip and coated by gold sputtering (SPI-Module Sputter Coater, PA, USA). Finally, samples were observed under a scanning electron microscope (JEOL JSM-5800 LV, Tokyo, Japan) using an acceleration voltage of $20 \mathrm{kV}$.

2.8. Experimental Design and Statistical Analysis. A completely randomized design of the factor (percentage of BPP) at three levels $(0,1$, and $2 \%)$ and a one-way analysis of variance were used. The data obtained were analyzed using
JMP software version 5.0.1. To compare differences among the means, a Tukey's multiple comparison test was used at a significance level of $5 \%$ and $n=3$. All determinations were performed in triplicate.

\section{Results and Discussion}

3.1. Study of Autolysis in Sols. Figure 1 shows the autolytic activity in sols obtained from giant squid mantle (Dosidicus gigas) at different temperatures and incubation times. For all incubation times, the amount of TCA-soluble peptides increased as the temperature increased from 20 to $35^{\circ} \mathrm{C}$, reaching a maximum at $35^{\circ} \mathrm{C}$. Subsequently, the amount of TCA-soluble peptides significantly decreased after incubation at $35-45^{\circ} \mathrm{C}$ and increased again at $55^{\circ} \mathrm{C}$. Finally, the content of soluble peptides decreased dramatically at $70^{\circ} \mathrm{C}$, probably due to the denaturation of the proteases.

In a study by Dublán-García et al. [17], the proteolytic activity of the squid mantle (Dosidicus gigas) as a function of $\mathrm{pH}$ and temperature was evaluated. An increase in the proteolytic activity at $35^{\circ} \mathrm{C}$ was observed. However, these researchers detected an increase in the proteolytic activity at $55^{\circ} \mathrm{C}$, which was attributed to the presence of cathepsin $\mathrm{L}$ because its optimum activity is near this temperature. A third increase in the proteolytic activity at $65^{\circ} \mathrm{C}$ was observed, which could be due to a heat-activated protease. The latter enzymes adversely impact quality, causing an excessive softening of the muscle in marine products, mainly due to the hydrolysis of myosin and other myofibrillar proteins involved in thermal gelation [18]. In a study carried out by Konno et al. [19], in which the thermal denaturation and autolytic protein profiles from squid mantle (Dosidicus gigas) were studied, it was found that mantle incubated at $25^{\circ} \mathrm{C}$ in $0.3 \mathrm{M} \mathrm{NaCl}$ had higher autolytic activity, but when the concentration was increased to $1 \mathrm{M}$, the activity gradually decreased. Albrecht-Ruiz and Solari [20] studied the proteolytic activity from squid mantle (Dosidicus gigas) and observed a higher activity between 30 and $40^{\circ} \mathrm{C}$ and another peak at approximately $50^{\circ} \mathrm{C}$. Our results, for which the maximum proteolytic activity from squid mantle was at $35^{\circ} \mathrm{C}$, are consistent with those reported by Albrecht-Ruiz and Solari [20] and Dublán-García et al. [17]. However, our results are different from those obtained by Konno et al. [19], who observed maximum activity at $25^{\circ} \mathrm{C}$, which could be related to the frozen storage time as well as the fishing season and the squid age. These results indicate that these enzymes are retained even during the washing process; therefore, the use of enzyme inhibitors is necessary.

In studies with other species of squid, Ayensa et al. [3] observed that the maximum autolytic activity in Todaropsis eblanae was at $45^{\circ} \mathrm{C}$ for washed muscle, while Benjakul et al. [5], working with lizard fish (Saurida tumbil), reported that the highest autolytic activity was observed between 60 and $65^{\circ} \mathrm{C}$ for chopped muscle. On the other hand, Kolodziejska and Sikorski [21] found that the optimum temperature for an extract from cod (Pacific Gadus morhua) was in a range from 30 to $45^{\circ} \mathrm{C}$. Therefore, these findings suggest that differences in the autolytic profile are a species-dependent phenomenon. 


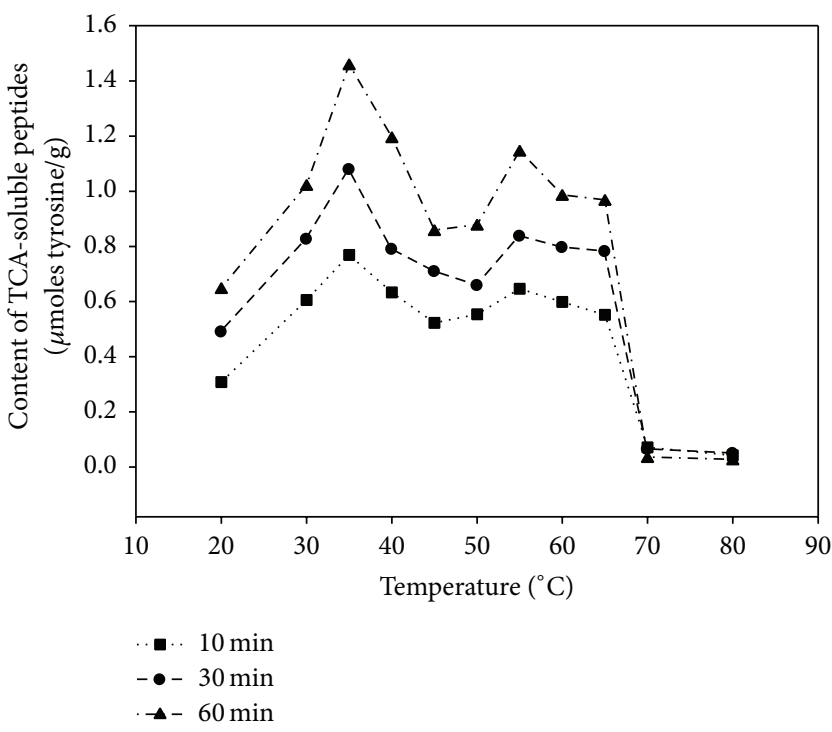

FIGURE 1: Effect of temperature and incubation time on the soluble peptides in TCA in sols from giant squid (Dosidicus gigas).

3.2. Effect of Bovine Plasma Protein (BPP) on the Inhibition of Autolysis in Sols. The inhibition of autolysis in sols containing 1 and $2 \% \mathrm{BPP}$ incubated at $35^{\circ} \mathrm{C}$ for $60 \mathrm{~min}$ is shown in Figure 2. These conditions were chosen based on results obtained in previous tests. As observed, sols without BPP showed higher autolytic activity, and major autolytic inhibition was observed with $2 \%$ BPP. This inhibition could be due to plasma inhibitors such as $\alpha$-macroglobulin, kininogen, and inhibitors of cysteine proteases, which can improve the thermal gelation of proteins [6, 22-24]. Similar results were obtained by Benjakul and Visessanguan [7], who reported that the BPP had greater inhibitory activity than porcine plasma protein (PPP) or ovalbumin (AH) for Pacific hake proteases (Merluccius gayi). In another study, Seymour et al. [25] evaluated the effect of BPP on protease inhibitory activity in Pacific hake (Merluccius gayi) and found that $1 \%$ BPP caused an inhibition of $78 \%$. The authors suggested that the inhibitory activity was due to the presence of plasma inhibitors such as $\alpha$-macroglobulin, which is an inhibitor with a similar structure to a natural substrate; hence, the active center of the protease recognizes and binds the inhibitor as a pseudosubstrate, but unlike a true substrate, it cannot be transformed. Thus, the substrate and inhibitor simultaneously compete for the active site of the enzyme.

\subsection{Molecular Characterization}

3.3.1. Total Sulfhydryl Content (TSH). Figure 3 shows the effect of the addition of BPP on the concentration of TSH in sols and gels. As expected, the TSH content in sols was the same $(p \geq 0.05)$ in all the treatments because the protein system had not yet undergone heat treatment. Moreover, the addition of BPP did not contribute to the TSH content, implying that BPP has a low $\mathrm{SH}$ group content. The decrease in TSH in the gels was expected during the gelation heat treatment because protein unfolding during heating increased the exposure of $\mathrm{SH}$ groups. Thiol groups

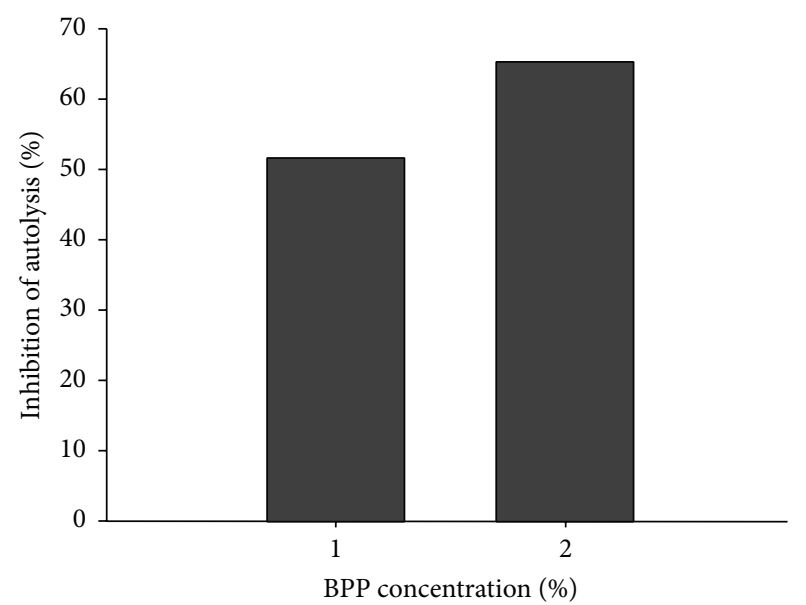

FIGURE 2: Effect of addition of BPP on the inhibition of the autolytic activity of sols from giant squid (Dosidicus gigas).

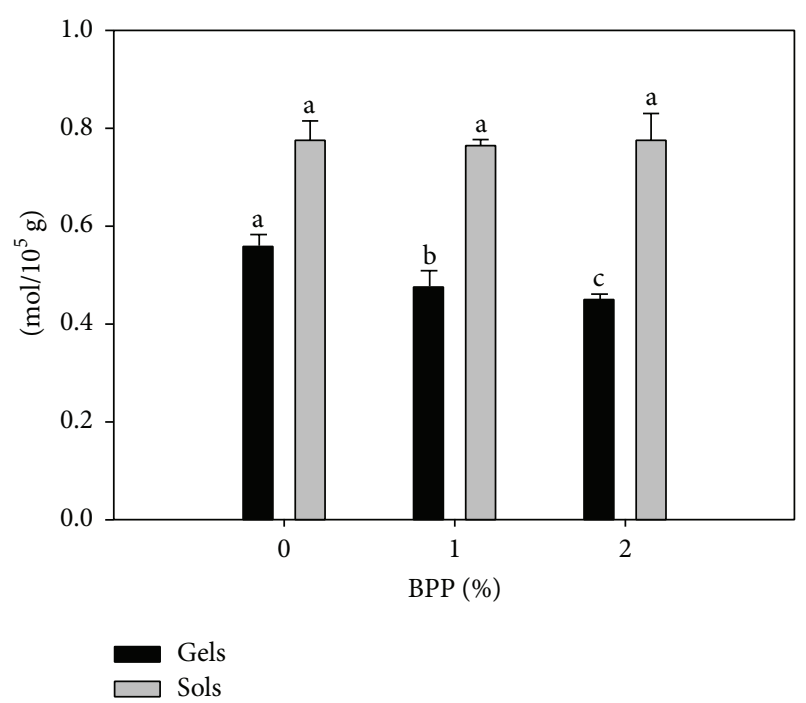

FIGURE 3: Effect of addition of BPP on the TSH content of sols and gels of protein concentrates from giant squid (Dosidicus gigas). Different letters in the same group bars (sol or gel) indicate significant differences $(p<0.05)$.

through an oxidation reaction can form disulfide bridges (SS) at temperatures above $50^{\circ} \mathrm{C}$. On the other hand, the TSH content decreased during gelation with an increase in the BPP concentration, which could be explained by the possible interaction between BPP and the S-1 fragment, promoting the formation of SS bonds [26]. A lower content of TSH indicates the major formation of SS bonds, which are related to gel strength obtained in the TPA. However, some researchers have reported that the formation of disulfide bonds is not a prerequisite for myosin gelation, because covalent disulfide bonds between polypeptide chains are involved in protein gelation and increase the apparent length of the polypeptide chain instead of acting as a stabilizer of the initial network; however, SS bonds contribute to the formation of the gel network, especially the S-1 fragment of the globular head [27].

3.3.2. Surface Hydrophobicity ( $S_{0} A N S$ ). Several recent studies have focused on studying the effect of added BPP on 
gelation properties in various marine species. However, no studies exist concerning the addition of BPP on conformational changes in proteins during gel formation in marine species. Therefore, we cannot compare the results of our study to those from other studies. Hence, we will explain the results based on the structural features of each protein system. Figure 4 shows the effect of adding BPP on surface hydrophobicity $\left(\mathrm{S}_{0}\right.$ ANS) in the sols. The three treatments showed linearity; however, sol without BPP gave a higher $r^{2}$. It could be due to the difficulty of the ANS to interact with hydrophobic regions in the presence of BPP. The hydrophobicity was reduced with the addition of BPP, possibly because of its physicochemical and structural characteristics. BPP is composed of soluble proteins containing hydrophilic residues that are generally exposed to water, while hydrophobic groups are generally located inside the molecule. Howell and Lawrie [28] studied plasma protein gelation with egg albumin and found a synergistic effect between the hydrophilic and hydrophobic residues. Their interactions varied with time, temperature, and the concentration of each protein in the mixture. In contrast, a combination of lysozyme with either $\alpha$-lactalbumin or $\beta$-lactoglobulin resulted in aggregation due to electrostatic interactions.

3.3.3. Electrophoretic Profile (SDS-PAGE). The electrophoretic patterns are shown in Figure 5. As shown, paramyosin (PM) and actin (AC) were the major proteins, with molecular weights of 97 and $45 \mathrm{kDa}$, respectively. The sols showed that MHC remained better as the concentration of BPP was increased. However, bands of PM and AC also showed greater intensity as the BPP level increased. These results indicate that the addition of BPP decreases the degradation of myofibrillar proteins, especially MHC, PM, and AC. Compared to the sols, a decrease in lower molecular weight bands and an increase in higher molecular weight bands were observed, which could be attributed to the formation of SS during heat treatment. Thus, the disulfide bond (SS) formation resulted in the formation of protein aggregates. Similar results have been reported by Rawdkuen et al. [29], who assessed the effect of the addition of chicken protein plasma (CPP) on the gelation of myofibrillar proteins from snapper (Priacanthus tayenus). In another study, Visessanguan et al. [24] evaluated the effect of adding of porcine plasma protein (PPP) on the rheological properties and texture of gels from Pacific hake (Merluccius gayi) and found that the degradation of myosin and actin in sols was inhibited by the addition of PPP.

\subsection{Macrostructural Characterization}

3.4.1. Water Holding Capacity (WHC). Gels with added BPP exhibited a very high WHC compared to those without the additive (Table 1). This result indicates that protein-water interactions are stronger within the three-dimensional network of gels containing BPP, probably due to the contribution of BPP, mainly albumin and globulin, which could have provided an open space to immobilize free water [30]. It could be possible due to a better electrostatic interaction

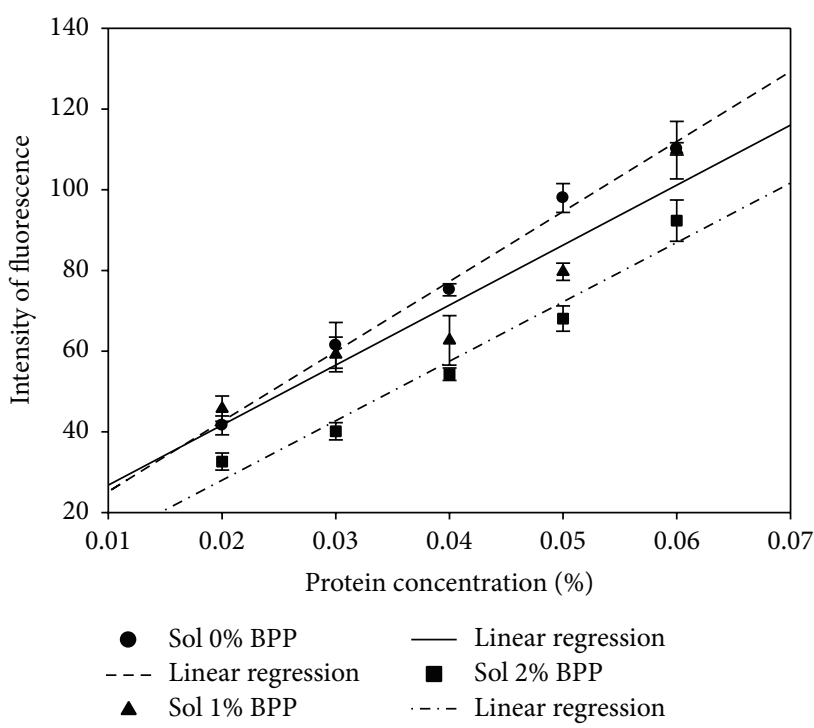

FIGURE 4: Effect of addition of BPP on the surface hydrophobicity of sols from giant squid (Dosidicus gigas).

TABLE 1: Effect of the BPP addition on the texture parameters and water holding capacity in gels.

\begin{tabular}{lccc}
\hline \multicolumn{4}{c}{ Treatments } \\
Parameter & BPP 0\% & BPP 1\% & BPP 2\% \\
\hline WHC & $82.34 \pm 0.75^{\mathrm{c}}$ & $88.57 \pm 0.14^{\mathrm{b}}$ & $94.24 \pm 0.36^{\mathrm{a}}$ \\
\hline Firmness (g) & $213.53 \pm 13.752^{\mathrm{c}}$ & $310.696 \pm 15.489^{\mathrm{b}}$ & $424.811 \pm 11.132^{\mathrm{a}}$ \\
$\begin{array}{l}\text { Adhesiveness } \\
\text { (g.sec) }\end{array}$ & $11.686 \pm 9.062^{\mathrm{a}}$ & $5.226 \pm 1.033^{\mathrm{c}}$ & $7.187 \pm 9.145^{\mathrm{b}}$ \\
Elasticity & $0.492 \pm 0.051^{\mathrm{c}}$ & $0.755 \pm 0.093^{\mathrm{a}}$ & $0.524 \pm 0.019^{\mathrm{b}}$ \\
Cohesiveness & $0.507 \pm 0.025^{\mathrm{c}}$ & $0.825 \pm 0.017^{\mathrm{b}}$ & $0.841 \pm 0.005^{\mathrm{a}}$ \\
\hline
\end{tabular}

Different superscripts in the same row indicate significant differences $(p<$ 0.05)

between the water ions and ionizable groups of proteins. Also it may be due to the formation of a better structured protein network, which is able to absorb water better. In gels without BPP, the lowest WHC could be related to the increased degradation of myofibrillar proteins, especially myosin, as a result of increased enzyme activity. Sánchez-González et al. [31] determined the WHC in gels made from Alaska Pollock (Theragra chalcogramma), finding a significant increase in the WHC in gels enriched with various protein additives, among them BPP, PPP, and whey proteins (WPC). In another study by Rawdkuen et al. [32], the effect of BPP on proteolysis and the ability to form gels were studied in sardine (Sardinella gibbosa), and the authors found that the WHC was improved.

3.4.2. Texture Profile Analysis (TPA). The TPA values are shown in Table 1. Higher hardness values were obtained with $2 \%$ BPP, probably because of higher autolytic inhibition resulting in a better protein-protein interaction. Although squid proteins are characterized by a poor gelling ability, the toughness obtained in this study was higher than that reported by Benjakul et al. $[5,22]$, who evaluated the effect of chicken plasma protein (CPP) on the gelling properties of proteins from snapper (Priacanthus tayenus) and lizardfish 


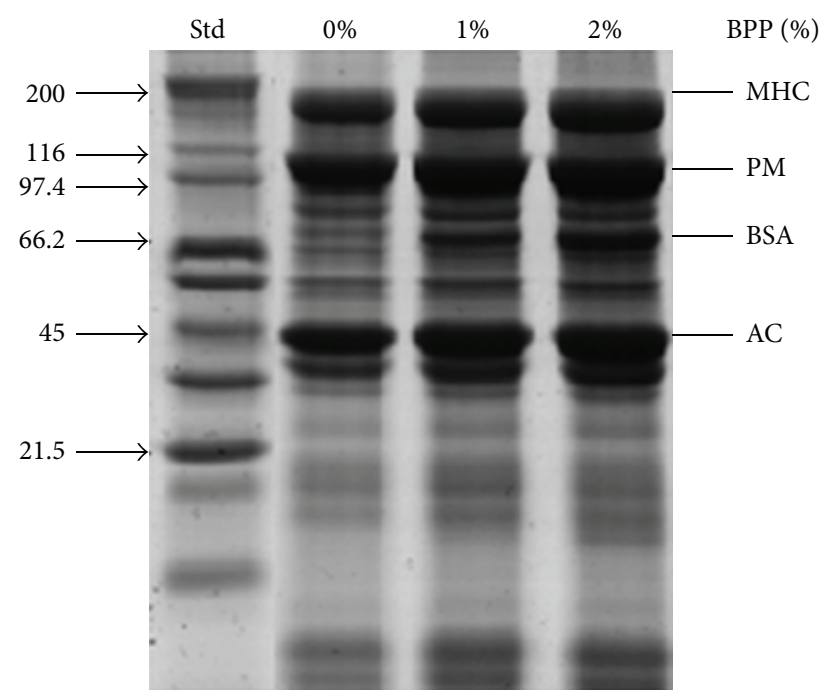

(a)

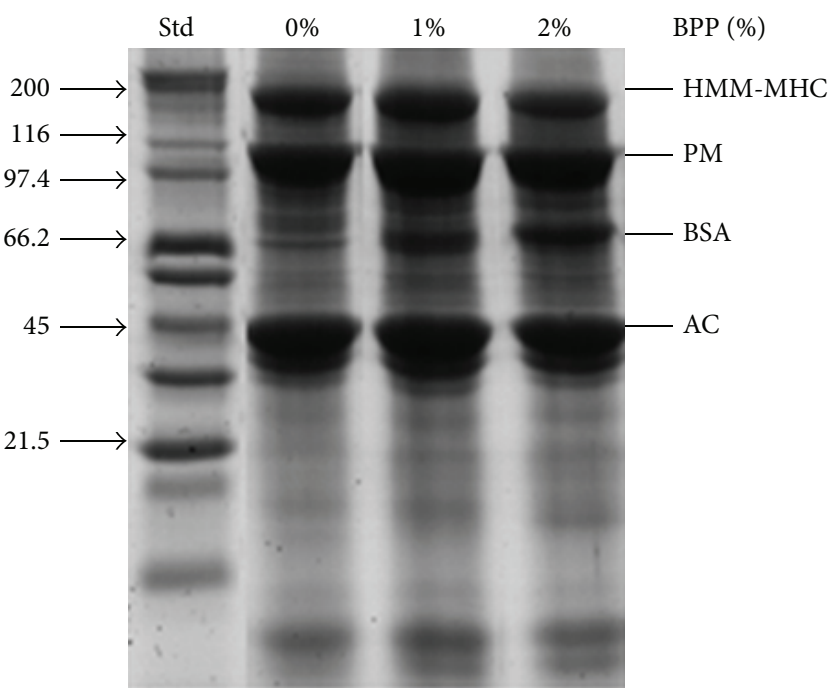

(b)

FIGURE 5: Electrophoretic profile of proteins of sols (a) and gels (b) from giant squid (Dosidicus gigas) added with different concentrations of $\operatorname{BPP}(0,1$, and $2 \%)$. Line 1: marker of broad range (Std); line 2: sol control; line 3: sol with 1\% BPP; line 4: sol with $2 \%$ BPP. MHC, myosin heavy chain; PM, paramyosin; BSA, bovine serum albumin; AC, actin.

(Saurida tumbil), obtaining values of 198.56 and $225.32 \mathrm{~g}$ for 1 and 2\% CPP, respectively. Similarly, in a study by Morrissey et al. [9], in which the effect of the added PPP during the formation of surimi gels from Pacific hake (Merluccius gayi) was studied, values of 192 and $248 \mathrm{~g}$ were obtained for 1 and $3 \%$ PPP, respectively. However, Rawdkuen et al. [32], who studied the effect of added BPP on the gelling properties in sardine (Sardinella gibbosa), reported strength values of 756 and $899 \mathrm{~g}$ for 1 and 2\% BPP, respectively. These results suggest that these differences are species-dependent, due to the inherent characteristics of the proteins in each species.

Elasticity and cohesiveness were improved by adding BPP, which could be due to better protein-protein interactions. However, elasticity was higher in the sample with $1 \%$ BPP, which is consistent with results obtained in the viscoelasticity study, which shows higher crosslinking, possibly due to hydrophobic interactions. The lower elasticity obtained with $2 \%$ BPP could be attributed to the possible interference of the plasma proteins with the formation of a three-dimensional network between the myofibrillar proteins, especially myosin and actin.

3.4.3. Viscoelasticity. Figure 6 shows the effect of adding BPP on changes in the storage modulus $\left(G^{\prime}\right)$ during thermal gelation. Significant differences between the control (no BPP) and protein systems with added BPP were observed; a significant improvement with the addition of $1 \%$ BPP was detected. An initial increase in $G^{\prime}$ to almost $40^{\circ} \mathrm{C}$ in the control could be due to the formation of a flexible structure by myosin crosslinking [33], which generally begins at $25^{\circ} \mathrm{C}$ in most fish species proteins. Then, $G^{\prime}$ decreased from $40^{\circ} \mathrm{C}$, probably due to the dissociation of the myosin $\alpha$-helix, especially light meromyosin (tail portion) and the fragmentation of actin filaments, causing fluency [34]. However, the lowest $G^{\prime}$ value $\left(45-55^{\circ} \mathrm{C}\right)$ was probably caused by the proteolytic activity at these temperatures (the modori phenomenon).

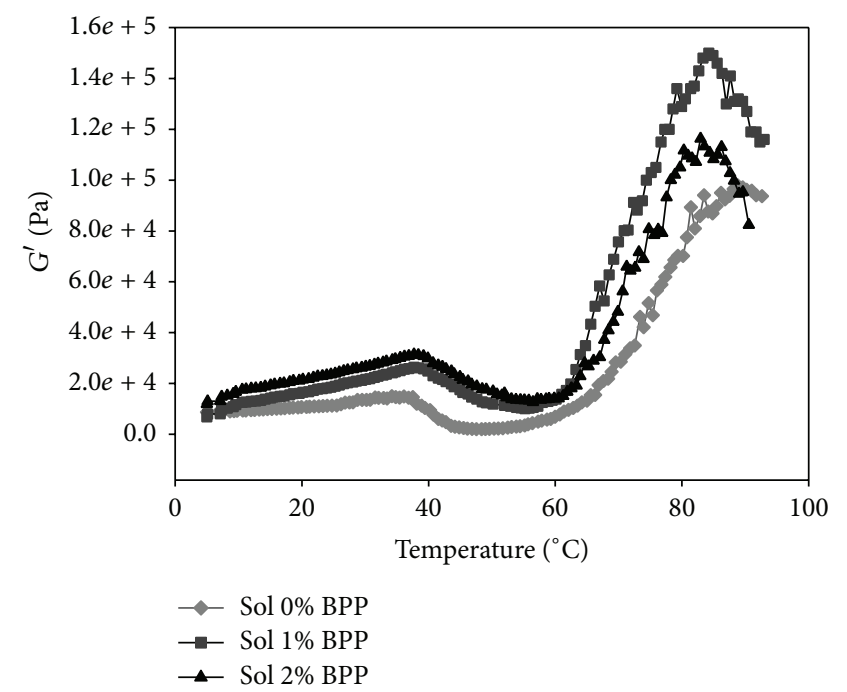

FIGURE 6: Effect of addition of BPP on changes in the storage modulus $\left(G^{\prime}\right)$ during heating of sols from giant squid (Dosidicus gigas).

The subsequent increase in $G^{\prime}$ has been attributed to the strengthening of a protein network from 50 to $85^{\circ} \mathrm{C}$ due to hydrophobic interactions [35].

The treatments containing BPP showed a maximum $G^{\prime}$ value at approximately $85^{\circ} \mathrm{C}$, whereas without BPP, the maximum peak elasticity was higher. This result could be attributed to the interaction of the BPP components and the protein concentrate. On the other hand, the addition of BPP caused an increase in the elastic behavior, which could be attributed to the protease inhibitory effect, decreasing the autolysis of myofibrillar proteins. Similar results were reported by Rawdkuen et al. [32], who studied the effect of adding chicken plasma proteins (CPP) at different levels $(0-3 \% \mathrm{w} / \mathrm{w})$ on the rheological properties and texture in 
TABLE 2: Effect of the BPP addition on the thermal behavior of sols.

\begin{tabular}{|c|c|c|c|c|c|c|}
\hline & \multicolumn{6}{|c|}{ Treatments } \\
\hline & \multicolumn{2}{|c|}{ ВРP \% } & \multicolumn{2}{|c|}{ ВРP 1\% } & \multicolumn{2}{|c|}{ ВРP \% } \\
\hline & $T_{d}\left({ }^{\circ} \mathrm{C}\right)$ & $\Delta H(\mathrm{~J} / \mathrm{g})$ & $T_{d}\left({ }^{\circ} \mathrm{C}\right)$ & $\Delta H(\mathrm{~J} / \mathrm{g})$ & $T_{d}\left({ }^{\circ} \mathrm{C}\right)$ & $\Delta H(\mathrm{~J} / \mathrm{g})$ \\
\hline Peak 1 & $44.54 \pm 0.36^{\mathrm{a}}$ & $0.47 \pm 0.01^{\mathrm{a}}$ & $44.98 \pm 0.43^{\mathrm{a}}$ & $0.53 \pm 0.07^{\mathrm{a}}$ & $45.32 \pm 0.31^{\mathrm{a}}$ & $0.61 \pm 0.03^{\mathrm{a}}$ \\
\hline Peak 2 & $70.93 \pm 0.15^{\mathrm{b}}$ & $0.23 \pm 0.014^{\mathrm{b}}$ & $72.67 \pm 0.29^{\mathrm{a}}$ & $0.33 \pm 0.08^{b}$ & $72.95 \pm 0.19^{\mathrm{a}}$ & $0.44 \pm 0.01^{\mathrm{b}}$ \\
\hline Peak 3 & $90.29 \pm 0.001^{\mathrm{a}}$ & $0.0136 \pm 0.01^{c}$ & $85.78 \pm 0.24^{\mathrm{b}}$ & $0.0067 \pm 0.01^{c}$ & $85.57 \pm 0.08^{b}$ & $0.0038 \pm 0.00^{\mathrm{c}}$ \\
\hline
\end{tabular}

Different superscripts in the same column indicate significant differences $(p<0.05)$.

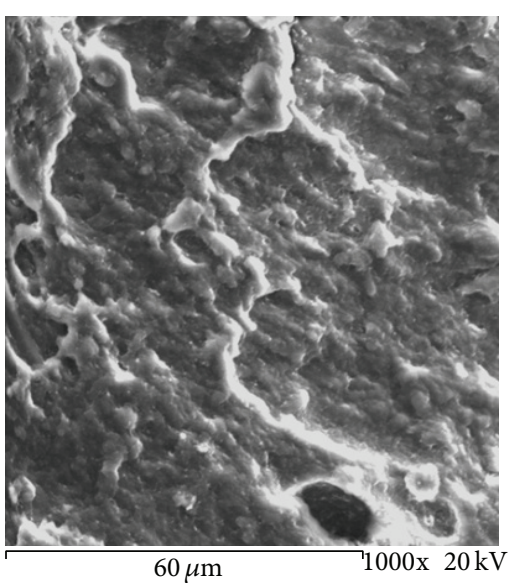

(a)

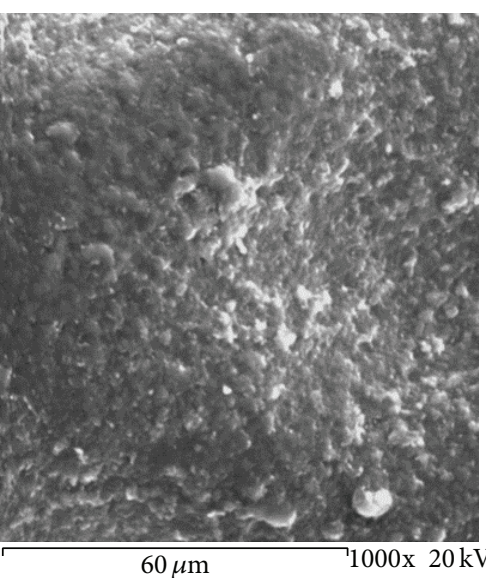

(b)

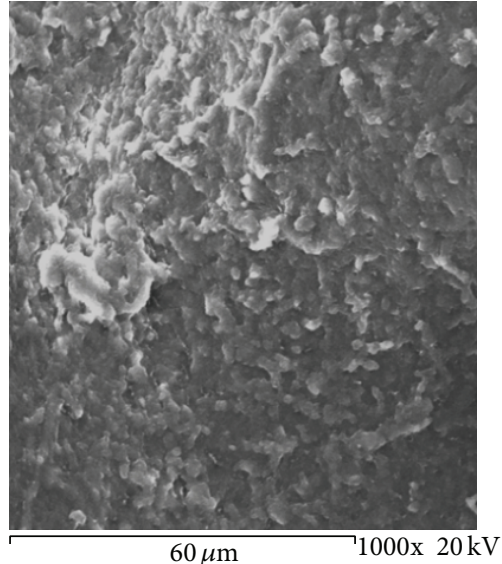

(c)

FIGURE 7: SEM micrographs obtained of gels from giant squid (Dosidicus gigas) added with BPP. (a) Gel control (0\% BPP), (b) gel with 1\% BPP, and (c) gel with $2 \%$ BPP.

Pacific hake (Merluccius gayi) proteins. These researchers found that 2 and 3\% CPP showed lower $G^{\prime}$ values and therefore hypothesized that CPP components interfere with gel formation. However, the gel strength was improved in both kamaboko and modori. Therefore, they concluded that the improvement in the gelling properties was due to the autolytic inhibition caused by endogenous proteases.

Sols with $1 \%$ BPP had higher $G^{\prime}$ values, which could be because a higher BPP concentration (2\%) impeded the hydrophobic interaction between proteins, causing a lower $G^{\prime}$ value. Similar results have been reported by Visessanguan et al. [24], who studied the effect of BPP on actomyosin gelation and found that 3\% BPP interfered with gelation, resulting in a lower $G^{\prime}$ value. However, these authors also found that it was possible to improve any type of interaction by changing the ionic strength, which could promote more orderly interactions.

\subsection{Microstructural Characterization}

3.5.1. Differential Scanning Calorimetry (DSC). The effect of added BPP on the phase transitions of proteins from giant squid (Dosidicus gigas) was investigated by differential scanning calorimetry (DSC). Table 2 shows the maximum denaturation temperature $\left(T_{d}\right)$ and the enthalpy of denaturation $(\Delta H)$ for the different protein systems. In sols without BPP, the denaturation profiles showed three endothermic peaks. Peak 1 likely corresponded to the denaturation temperature of myosin, a myofibrillar protein believed to be primarily responsible for gel formation, which had a $T_{d}$ of $44.54^{\circ} \mathrm{C}$ and a net thermal energy of $0.47 \mathrm{~J} / \mathrm{g}$. The second endothermic peak had a $T_{d}$ of $70.93^{\circ} \mathrm{C}$ and a $\Delta H$ of $0.23 \mathrm{~J} / \mathrm{g}$ and was probably due to the thermal transitions of actin, another myofibrillar protein present in muscle. Similar results were reported by Ramírez Olivas et al. [36], who studied the firmness and thermal behavior changes in jumbo squid mantle (Dosidicus gigas) stored in ice. They reported that thermal transitions of myosin and actin occurred at 50 and $79^{\circ} \mathrm{C}$, respectively. Finally, the third endothermic peak can be attributed to collagen or paramyosin.

Three endothermic transition peaks were obtained in sols with added BPP. As shown in Table 2, peaks 1 and 2 might correspond to myosin and actin denaturation, respectively. No significant differences $(p<0.05)$ were detected in myosin denaturation; however, peak 2 showed a significant increase that could be attributed to a possible interaction between BPP and the protein concentrate. For peak 3 , protein systems with added BPP had a $T_{d}$ of $85.78 \pm 0.24$ and $85.57 \pm 0.08$ for 1 and $2 \%$ BPP, respectively. The former $T_{d}$ was similar to the maximum peak detected in the viscoelasticity experiment, which could be attributed to the protein components of BPP; their low enthalpy indicates that they are a minor protein component; therefore, the energy required to achieve denaturation was very low compared with peaks 1 and 2 .

3.5.2. Scanning Electron Microscopy (SEM). The microstructure of giant squid (Dosidicus gigas) gels with added BPP $(0$, 1 , and $2 \%$ ) was visualized by SEM, as shown in Figure 7. It was noted that the gel microstructure without BPP showed 
a structured protein matrix, but it was disorganized and had a globular surface appearance. Furthermore, gels containing 1 and 2\% BPP had a more dense and compact matrix compared to the control, with a lower porosity and higher order. However, microstructure of the gel containing 1\% BPP showed a more compact and structured protein network, which could explain the higher $G^{\prime}$ for this treatment. According to viscoelastic and SEM analysis, treatment with $1 \%$ BPP formed a more ordered gel, whereas TPA indicated that the best treatment was $2 \%$ BPP. This finding could be explained due to differences in the physicochemical properties of the proteins as a function of temperature. At high temperatures $\left(80-90^{\circ} \mathrm{C}\right)$, hydrophobic interactions are favored, causing an increase in the elastic modulus; once the gel is cooled, electrostatic interactions predominate (which was when texture was measured). Therefore, it is likely that a higher BPP content decreases hydrophobic interactions in proteins from protein concentrate.

On the other hand, as shown in the electrophoretic profile, the added proteins (albumin and globulin) did not induce crosslinking of the myofibrillar protein from giant squid (Dosidicus gigas) but rather interacted through hydrophobic and electrostatic interactions, acting as a filler between the protein network and improving the strength and resilience.

\section{Conclusions}

The addition of BPP to protein concentrates obtained from giant squid mantle partially inhibited endogenous proteolytic activity and was reflected by improved functional properties. BPP impeded hydrophobic interactions at high temperatures, but once the protein system was cooled, the electrostatic interactions between different protein structures were favored, causing more rigid, more elastic, more cohesive, and better organized gels, thereby improving their gelation ability.

\section{Conflict of Interests}

The authors declare that they have no conflict of interests.

\section{References}

[1] C. Murrieta-Martínez, J. Ezquerra-Brauer, V. Ocaño-Higuera, F. Cinco-Moroyoqui, W. Torres-Arreola, and E. Márquez-Ríos, "Aislamiento y caracterización parcial de miosina del manto de calamar gigante (Dosidicus gigas)," CyTA-Journal of Food, vol. 13, no. 3, pp. 392-399, 2014.

[2] J. A. Cortés-Ruiz, R. Pacheco-Aguilar, M. Elena Lugo-Sánchez, M. Gisela Carvallo-Ruiz, and G. García-Sánchez, "Production and functional evaluation of a protein concentrate from giant squid (Dosidicus gigas) by acid dissolution and isoelectric precipitation," Food Chemistry, vol. 110, no. 2, pp. 486-492, 2008.

[3] M. G. Ayensa, M. P. Montero, A. J. Borderías, and J. L. Hurtado, "Influence of some protease inhibitors on gelation of squid muscle," Journal of Food Science, vol. 67, no. 5, pp. 1636-1641, 2002.
[4] K. Konno and C. Fukazawa, "Autolysis of squid mantle muscle protein as affected by storage conditions and inhibitors," Journal of Food Science, vol. 58, no. 6, pp. 1198-1202, 1993.

[5] S. Benjakul, W. Visessanguan, J. Tueksuban, and M. Tanaka, "Effect of some protein additives on proteolysis and gel-forming ability of lizardfish (Saurida tumbil)," Food Hydrocolloids, vol. 18, no. 3, pp. 395-401, 2004.

[6] I. S. Kang and T. C. Lanier, "Bovine plasma protein functions in surimi gelation compared with cysteine protease inhibitors," Journal of Food Science, vol. 64, no. 5, pp. 842-846, 1999.

[7] S. Benjakul and W. Visessanguan, "Pig plasma protein: potential use as proteinase inhibitor for surimi manufacture; inhibitory activity and the active components," Journal of the Science of Food and Agriculture, vol. 80, no. 9, pp. 1351-1356, 2000.

[8] AOAC, Official Methods of Analysis, Association of Official Analytical Chemists, Washington, DC, USA, 18th edition, 2005.

[9] M. T. Morrissey, J. W. Wu, D. D. Lin, and H. An, "Effect of food grade protease inhibitor on autolysis and gel strength of surimi," Journal of Food Science, vol. 58, pp. 1050-1054, 1993.

[10] O. H. Lowry, N. J. Rosebrough, A. L. Farr, and R. J. Randall, "Protein measurement with the Folin phenol reagent," The Journal of Biological Chemistry, vol. 193, no. 1, pp. 265-275, 1951.

[11] P. S. Patrick and H. E. Swaisgood, "Sulfhydryl and disulfide groups in skim milk as affected by direct ultra-hightemperature heating and subsequent storage," Journal of Dairy Science, vol. 59, no. 4, pp. 594-600, 1976.

[12] A. Kato and S. Nakai, "Hydrophobicity determined by a fluorescence probe method and its correlation with surface properties of proteins.", Biochimica et Biophysica Acta, vol. 624, no. 1, pp. 13-20, 1980.

[13] U. K. Laemmli, "Cleavage of structural proteins during the assembly of the head of bacteriophage T4," Nature, vol. 227, no. 5259, pp. 680-685, 1970.

[14] S. Jiang, M. Ho, and T. Lee, "Optimization of the freezing conditions on mackerel and amberfish for manufacturing minced fish," Journal of Food Science, vol. 50, pp. 727-732, 1985.

[15] L. Campo-Deaño, C. A. Tovar, M. Jesús Pombo, M. Teresa Solas, and A. Javier Borderías, "Rheological study of giant squid surimi (Dosidicus gigas) made by two methods with different cryoprotectants added," Journal of Food Engineering, vol. 94, no. 1, pp. 26-33, 2009.

[16] M. E. Paredi, M. C. Tomas, M. C. Añon, and M. Crupkin, "Thermal stability of myofibrillar proteins from smooth and striated muscles of scallop (Chlamys tehuelchus): a Differential Scanning Calorimetric Study," Journal of Agricultural and Food Chemistry, vol. 46, no. 10, pp. 3971-3976, 1998.

[17] O. Dublán-García, R. Cruz-Camarillo, I. Guerrero-Legarreta, and E. Ponce-Alquicira, "Effect of refrigerated storage on proteolytic activity and physicochemical and microstructural properties of giant squid (Dosidicus gigas) mantle muscle," Journal of Muscle Foods, vol. 17, no. 3, pp. 291-310, 2006.

[18] N. F. Haard, "Protein hydrolysis in seafoods," in Seafood Chemistry. Processing Technology and Quality, C. H. F. Shahidi and J. R. Botta, Eds., Chapman and Hall, London, UK, 1994.

[19] K. Konno, C. Young-Je, T. Yoshioka, P. Shinho, and N. Seki, "Thermal denaturation and autolysis profiles of myofibrillar proteins of mantle muscle of jumbo squid Docidicus gigas," Fisheries Science, vol. 69, no. 1, pp. 204-209, 2003.

[20] M. Albrecht-Ruiz and A. y Solari, "Aspectos de actividad proteolítica en el músculo de pota," Boletín de Investigación del Instituto Tecnológico Pesquero de Perú, vol. 7, pp. 31-37, 2006. 
[21] I. Kolodziejska and Z. E. Sikorski, "Muscle cathepsins of marine fish and invertebrates," Polish Journal of Food and Nutrition Sciences, vol. 45, pp. 3-10, 1995.

[22] S. Benjakul, W. Visessanguan, and C. Srivilai, "Porcine plasma protein as proteinase inhibitor in bigeye snapper (Priacanthus tayenus) muscle and surimi," Journal of the Science of Food and Agriculture, vol. 81, no. 10, pp. 1039-1046, 2001.

[23] J.-J. Lee, S.-S. Tzeng, J. Wu, and S.-T. Jiang, "Inhibition of thermal degradation of mackerel surimi by pig plasma protein and L-kininogen," Journal of Food Science, vol. 65, no. 7, pp. 1124-1129, 2000.

[24] W. Visessanguan, S. Benjakul, and H. An, "Porcine plasma proteins as a surimi protease inhibitor: effects on actomyosin gelaton," Journal of Food Science, vol. 65, no. 4, pp. 607-611, 2000.

[25] T. A. Seymour, M. T. Morrissey, M. Y. Peters, and H. An, "Purification and characterization of pacific whiting proteases," Journal of Agricultural and Food Chemistry, vol. 42, no. 11, pp. 2421-2427, 1994.

[26] J. D. J. Encinas-Arzate, J. M. Ezquerra-Brauer, V. M. OcañoHiguera et al., "Effect of ionic strength on soluble protein removal from giant squid mantle (Dosidicus gigas) and functional evaluation of protein recovery," Food Science and Biotechnology, vol. 23, no. 2, pp. 401-407, 2014.

[27] A. Totosaus, J. G. Montejano, J. A. Salazar, and I. Guerrero, "A review of physical and chemical protein-gel induction," International Journal of Food Science and Technology, vol. 37, no. 6, pp. 589-601, 2002.

[28] N. K. Howell and R. A. Lawrie, "Functional aspects of blood plasma proteins. II. Gelling properties," Journal of Food Technology, vol. 19, pp. 289-295, 1984.

[29] S. Rawdkuen, S. Benjakul, W. Visessanguan, and T. C. Lanier, "Fractionation and characterization of cysteine proteinase inhibitor from chicken plasma," Journal of Food Biochemistry, vol. 29, no. 5, pp. 486-503, 2005.

[30] M. R. Torres, F. R. Marín, A. J. Ramos, and E. Soriano, "Study of operating conditions in concentration of chicken blood plasma proteins by ultrafiltration," Journal of Food Engineering, vol. 54, no. 3, pp. 215-219, 2002.

[31] I. Sánchez-González, P. Carmona, P. Moreno et al., "Protein and water structural changes in fish surimi during gelation as revealed by isotopic H/D exchange and Raman spectroscopy," Food Chemistry, vol. 106, no. 1, pp. 56-64, 2008.

[32] S. Rawdkuen, S. Benjakul, W. Visessanguan, and T. C. Lanier, "Effect of chicken plasma protein and some protein additives on proteolysis and gel-forming ability of sardine (Sardinella Gibbosa) surimi," Journal of Food Processing and Preservation, vol. 31, no. 4, pp. 492-516, 2007.

[33] T. Sano, S. F. Noguchi, T. Tsuchiya, and J. J. Matsumoto, "Dynamic viscoelastic behavior of natural actomyosin and myosin during termal gellation," Journal of Food Science, vol. 53, no. 3, pp. 924-928, 1988.

[34] E. Niwa, Y. Matsuura, A. A. K. Nowsad, and S. Kanoh, "Speciesspecificity ofsuwari gel-formability offlesh fish paste in which transgutaminase was inactivated," Fisheries Science, vol. 61, pp. 107-109, 1995.

[35] Y. L. Xiong, "Structure-function relationships of muscle proteins," in Food Proteins and Their Applications, S. Damodaran and A. Paraf, Eds., pp. 341-392, Marcel Dekker, New York, NY, USA, 1997.

[36] R. Ramírez Olivas, O. Rouzaud Sández, N. F. Haard, R. Pacheco Aguilar, and J. M. Ezquerra Brauer, "Changes in firmness and thermal behavior of ice-stored muscle of jumbo squid (Dosidicus gigas)," European Food Research and Technology, vol. 219, no. 4, pp. 312-315, 2004. 

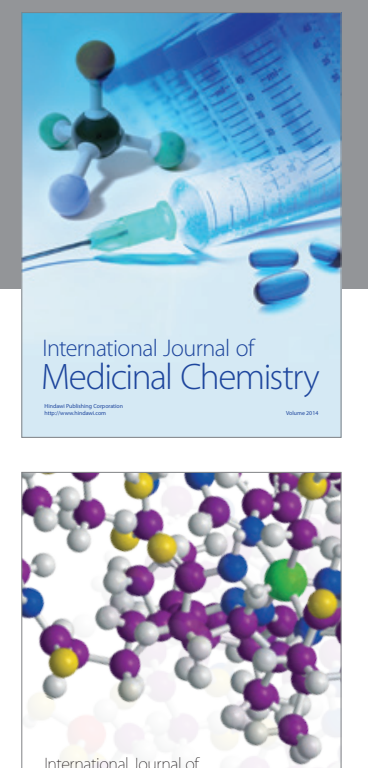

\section{Carbohydrate} Chemistry

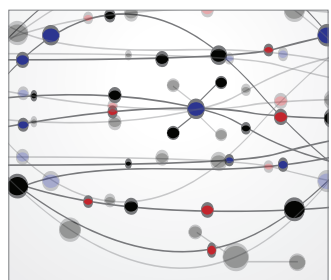

The Scientific World Journal
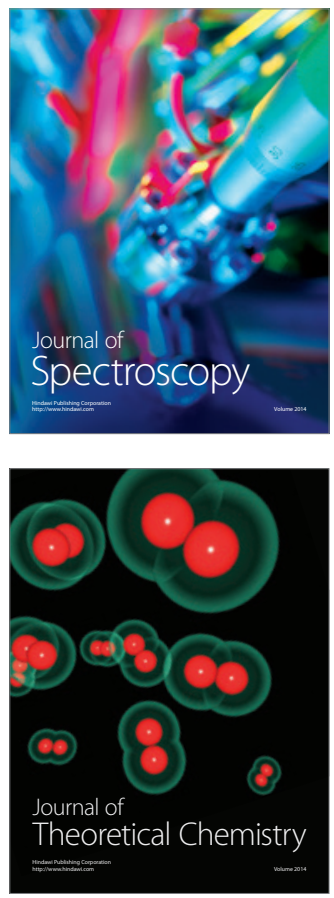
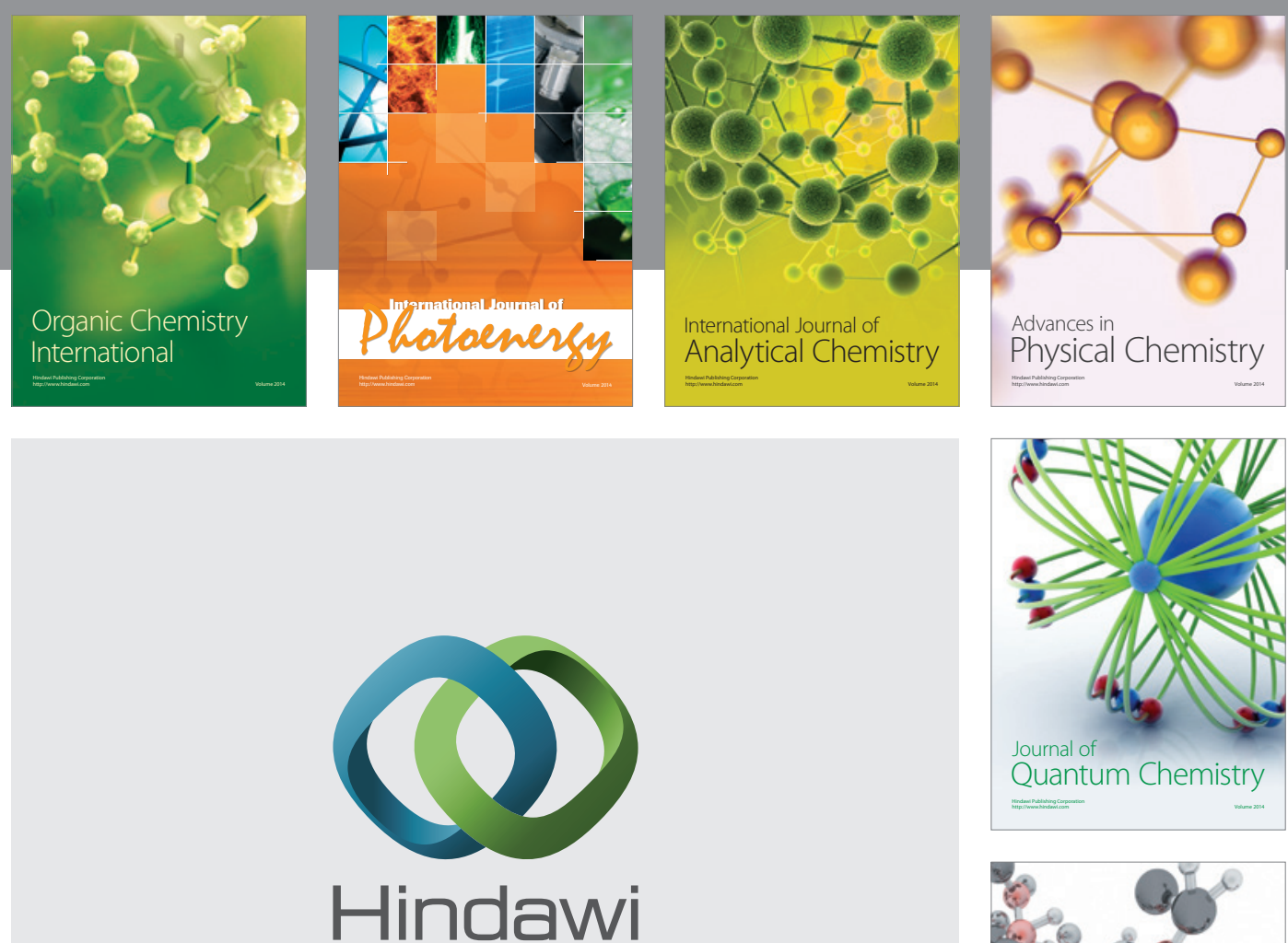

Submit your manuscripts at

http://www.hindawi.com

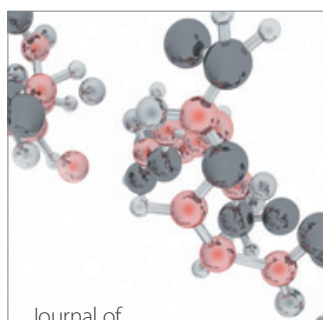

Analytical Methods

in Chemistry

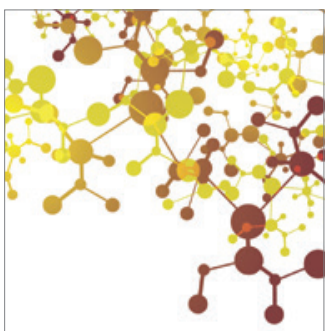

Journal of

Applied Chemistry

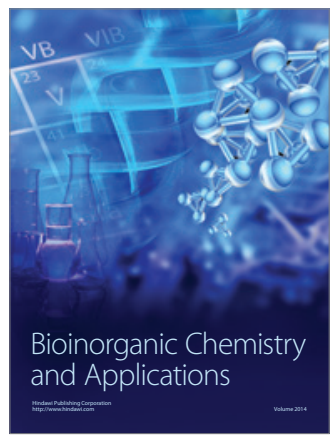

Inorganic Chemistry
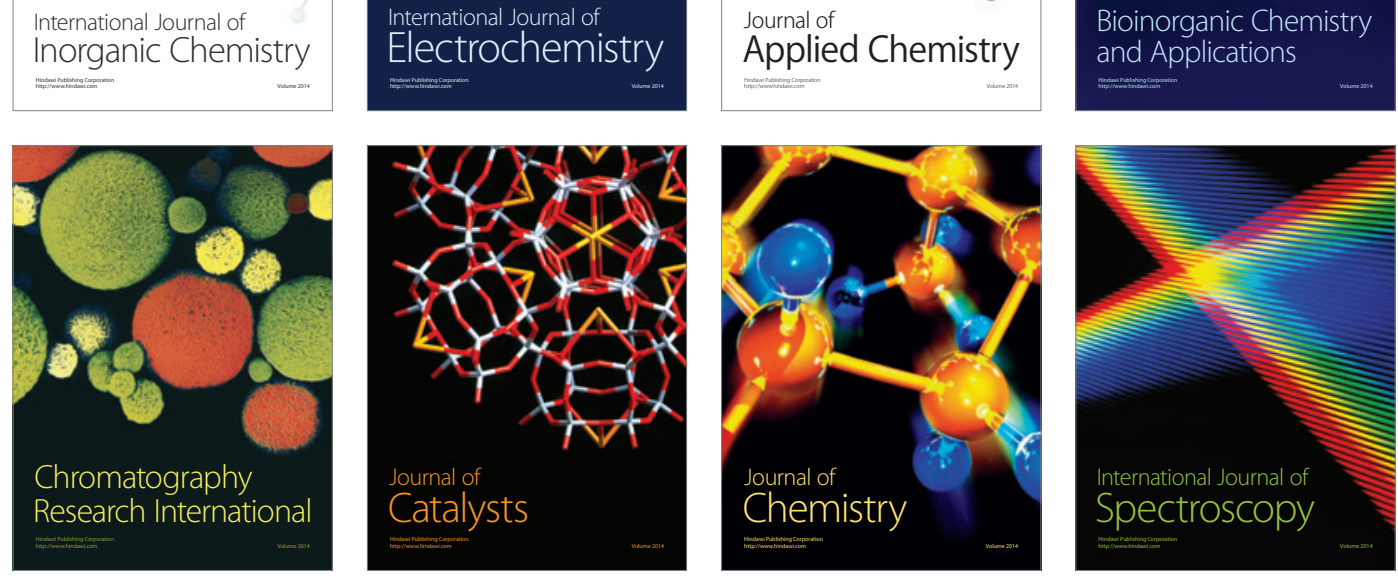